\title{
Shelf-Life and Acceptability of Hot Water-Treated Mangos'
}

\author{
Noemí Díaz, Teresita Rodriguez and Isabel $B$. de Coloni"
}

\begin{abstract}
Mangos given hot water treatments for $0,90,120,150$ and $180 \mathrm{~min}$ utes, followed by cold storage for seven and 14 days, were sensoryevaluated for overall quality, shelf life, and percentage fruit decay. Hot water treatment did not affect the physical, chemical and organoleptic characteristics studied. The decay observations indicate that fruits held for seven days in cold storage $\left(50-55^{\circ} \mathrm{F}\right.$ and $\left.85-90 \% \mathrm{RH}\right)$ should be of good marketing quality for up to 12 days. If kept for 14 days in cold starage, they should be marketed within four to five days after removal from the cold.
\end{abstract}

\section{RESUMEN}

Durabilidad y aceptación del mangó tratado con agua caliente

Como fa Ageneia de Proteceión Ambiental proscribió el dibromuro de etileno (EDB) hay que buscar alternativas para cumplir con los requisitos de cuarentena del Departamento de Agricultura de los Estados Unidos. Una de las posibles alternativas al uso del EDB para controlar las mosca frutera en el mangó es el tratamiento con agua caliente. Para probar esta alternativa se hizo una investigación para determinar el efecto de diferentes tratamientos con agua caliente sobre la duración en almacenamiento, la maduración, la descomposición poscosecha, la composición química y las caracteristicas organolépticas de los mangos de las variedades Keitł, Irwin y Parvin. Se obtuvieron 5 grupos de 88 frutas cada uno de cada una de las variedades mencionadas. Cada grupo se sumergió en agua caliente $\left(46.1^{\circ} \mathrm{C} 6115^{\circ} \mathrm{F}\right)$ por diferentes tiempos según el protocolo de trabajo establecido por el Departamento de Agricultura de los Estados Unidos los tiempos de inmersión fueron $0,90,120,150$ y 180 minutos. En adición, se hicieron estudios de penetratión de calor para determinar la temperatura interna de los mangos cuando se sometían a los tratamientos con agua caliente. Se encontró que para que la temperatura más baja llegue a ser letal $\left(40.6^{\circ} \mathrm{C} 6105^{\circ} \mathrm{F}\right)$, se requieren 50 minutos de inmersión. Los resultados obtenidos indican que los tratamientos de agua caliente que se usaron no afectaron apreciablemente la composición química ni la aceptabilidad organoléptica de ninguna de las tres variedades de mangó estudiadas. El estudio indica que las frutas sometidas al tratamiento con agua caliente si se almacenan por 7 días en cámaras ambientales entre 50 y $55^{\circ} \mathrm{F}$ y a una humedad relativa de entre 85 y $90 \%$, se deben mercadear dentro de los próximos 10 a 12 días a tempera-

'Manuseript submitted to Editorial Board 9 June 1988.

Food Technologist, Research Associate, and Food Technologist respectively, Food Technology Laboratory, Agricultural Experiment Station, Rio Piedras, Puerto Rico. 


\begin{abstract}
tura ambiente y si se almacenan por 14 días bajo los mismas condiciones anteriores, se deben mercadear dentro de los próximos 4 a 5 días luego de sacarlas de las cámaras ambientales.
\end{abstract}

\title{
INTRODUCTION
}

Effective September 1, 1985, the U. S. Environmental Protection Agency banned ethylene dibromide (EDB) as fumigant for all fruits intended for consumption in the United States (3). The Caribbean fruit fly (Anastrepha obliqua) is a major pest infesting mangoes exported to the U. S. mainland. Therefore, for commerce involving mangoes, an alternative method must be found that kills the fruit fly without adversely affecting fruit quality.

Hot-water immersion of mangoes has reduced post-harvest decay in Florida mangoes (5). It has also been proposed as an alternative to ethylene dibromide (EDB) for the control of the Caribbean fruit fly in mangoes $(6,5)$. Immersion at $46.1^{\circ} \mathrm{C}\left(115^{\circ} \mathrm{F}\right)$, for 65 minutes destroyed A. suspensa in Florida mangoes without visible injury to the fruit (5).

In Puerto Rico, A. obliqua has been identified as the species present in mango varieties of economic importance (4). Puerto Rico presently has no approved alternative to control this inseet without adversely affecting fruit quality and shelf-life. When satisfactory controls are available, Puerto Rico can export mangoes to the U. S. mainland, whereas at present local farmers are obliged to export their fruits to Europe at their own expense. This situation leaves local farmers uncompetitive with foreign producers who are subsidized to market their produce in other countries.

Hot water immersion of mangoes for control of post-harvest decay has been reported by several investigators $(1,2,7,8)$. It also controls the Caribbean fruit fly. The present investigations were performed to determine hot-water immersion effects on the shelf life and quality of mangoes submitted to this treatment.

\section{MATERIALS AND METHODS}

The research work reported herein complies with the protocol submitted by the USDA-ARS.

Five hundred mature-green mangoes of each of three varieties (Irwin, Parvin and Keitt) were utilized. Some 440 "sound" fruits of each group were separated for study. Each group was in turn separated into five subgroups of 88 fruits each. The subgroups were subjected to different immersion intervals in hot water $\left(46.1^{\circ} \mathrm{C}\right.$ or $\left.115^{\circ} \mathrm{F}\right)$, consisting of 0,90 , 120,150 and 180 minutes. After hot-water immersion they were subjected to cold storage $\left(50-55^{\circ} \mathrm{F}\right)$ for periods of 7, 14 and 21 days. Post-harvest decay, ripening, chemical analyses and organoleptic analyses for each immersion time were assessed in accordance with the USDA-ARS protocol. The only variation from the established protocol was that, 
instead of fruits being stored in a cooled room, they were held in an environmental chamber at the prescribed temperatures under controlled humidity $(85-90 \% \mathrm{RH})$ to avoid shrinkage.

Heat-penetration studies were performed to determine the internal temperature of the mangoes. Eleven fruits of each variety were selected on the basis of their comparatively larger size (size 8). Needle-type thermocouples were introduced crosswide through the widest part of the mango and pushed until the tip touched the seed of the fruit. The mangoes were then completely submerged under water at $115^{\circ} \mathrm{F}\left(46.1^{\circ} \mathrm{C}\right)$ for 180 minutes. The internal temperatures of each mango were registered initially and at 5-minute intervals with a Kaye Digistrip 4 (Kaye Instruments Ine., Bedford, MA.). ${ }^{3}$

After the hot water temperatures, the mangoes were drained and cooled to room temperatures before being placed in cold storage. After seven days the fruits were removed from cold storage for evaluaiton of chemical composition, texture, and sensory parameters.

\section{RESULTS AND DISCUSSION}

The heat penetration determinations indicated that Keitt variety was the slowest-heating fruit, requiring 50 minutes to reach $105^{\circ} \mathrm{F}\left(40.6^{\circ} \mathrm{C}\right)$ and 120 minutes to reach $115^{\circ} \mathrm{F}\left(46.1^{\circ} \mathrm{C}\right)$. Since we used size 8 Keitts, heat penetration data obtained for this variety can be valid for the other two varieties tested.

Results of the chemical evaluations after immersion and cold-storage appear in tables 1,2 , and 3 . In all 3 varieties the values for soluble solids ( $\left.{ }^{\circ} \mathrm{Brix}\right), \mathrm{pH}$, total acidity (expressed as percentage of citric acid) and total sugars did not vary appreciably. Texture values, as determined by shear press, indicated marked differenees in firmness of the mature green fruit of Keitt variety, suggesting a greater fruit tolerance to handling procedures at this stage. These results suggest that hot-water treatments did not affect any of the physical and chemical characteristics assessed for any of the varieties.

Table 4 presents the results of organoleptic analysis obtained by taste panel. The data suggest that hot water treatments do not affect the sensory attributes of the mango varieties studied. With the most severe heat treatment (180 min.) as an example, the general acceptability of the mangoes rated comparably to controls for varieties Irwin and Parvin, and superior to the control for variety Keitt. The same trend was ob-

Trade names in this publication are used only to provide specific information. Mention of a trade name does not constitute a warranty of equipment of materials by the Agricultural Experiment Station of the University of Puerto Rico, nor is this mention a statement of preference over other equipment or materials. 
TABLE 1.-Properties of Irwin mangos subjected to different immersion intervals in hot water at $46.1^{\circ} \mathrm{C}\left(115^{\circ} \mathrm{F}\right)$.

\begin{tabular}{lccccc}
\hline & \multicolumn{5}{c}{ Properties After 7 days eold storage (60-65 $\left.{ }^{\circ} \mathrm{F}, 10-12^{\circ} \mathrm{C}\right)$} \\
\cline { 2 - 6 } $\begin{array}{l}\text { Interval } \\
\text { (minutes) }\end{array}$ & $\begin{array}{c}\text { Shear } \\
\text { (lbs/g) }\end{array}$ & ${ }^{\circ}$ Brix & $\mathrm{pH}$ & $\begin{array}{c}\text { Acidity } \\
(\%)\end{array}$ & $\begin{array}{c}\text { Sugars } \\
(\%)\end{array}$ \\
\hline & & & & & \\
90 & 0.445 & 16.2 & 4.32 & 0.26 & 15.08 \\
120 & 0.415 & 15.3 & 4.15 & 0.37 & 13.76 \\
150 & 0.483 & 15.5 & 4.21 & 0.31 & 14.16 \\
180 & 0.403 & 15.4 & 4.19 & 0.33 & 13.85 \\
Control & 0.465 & 15.3 & 3.97 & 0.46 & 14.78 \\
Green state $^{2}$ & 6.830 & 7.3 & 3.65 & 0.75 & 4.39 \\
\hline
\end{tabular}

tMeasured values are the average of ten fruits.

'Before hot water treatment.

served for specific parameters of appearance, flavor, and texture. These observations are of very practical importance. They suggest that even extended hot-water intervals for fruit fly destruction would not alter materially the appearnce, flavor, texture and general acceptability of any of the three varieties currently evaluated.

Observations on non-marketable fruits bearing evidence of anthracnose, stem-end rot, blossom-end rot or mechanical damage were recorded as decayed fruits in general, together with failure to ripen. These observations were recorded at 7,14 and 21 days in cold storage, following hot-water submersion, and thereafter until the fruits were not marketable. The results are summarized in Table 5. Irwin mangoes ripened completely within 5 days after removal from cold storage, irrespective of the hot-water treatment given. As compared to the control, the incidence of decayed fruits was generally not different when fruits stood at room temperatures for as long as 19 days after removal from cold storage. For Irwin variety, stored 14 days, ripening was complete within 7 days after removal from the cold. For Parvin and Keitt varieties ripening was com-

TABLE 2.-Properties of Parvin mangos subjected to different immersion intervals in hot water at $46.1^{\circ} \mathrm{C}\left(115^{\circ} F^{\circ}\right)$.

\begin{tabular}{lccccc}
\hline & \multicolumn{5}{c}{ Properties after 7 days cold storage $\left(50-555^{\circ} \mathrm{F}, 10-12^{\circ} \mathrm{C}\right)^{\prime}$} \\
\cline { 2 - 6 } $\begin{array}{l}\text { Inter'val } \\
\text { (minutes) }\end{array}$ & $\begin{array}{c}\text { Shear } \\
\text { (lbs/g) }\end{array}$ & oBrix & $\begin{array}{c}\text { Aeidity } \\
\mathrm{pH}\end{array}$ & $\begin{array}{c}\text { Sugars } \\
(\%)\end{array}$ & $(\%)$ \\
\hline 90 & 0.55 & 17.6 & 4.20 & 0.33 & 16.23 \\
120 & 0.40 & 18.8 & 4.19 & 0.36 & 15.90 \\
150 & 0.72 & 18.4 & 4.19 & 0.42 & 16.01 \\
180 & 0.58 & 17.2 & 4.29 & 0.33 & 15.10 \\
Control & 0.37 & 18.6 & 4.20 & 0.28 & 16.63 \\
Green State & 8.63 & 8.2 & 8.62 & - & 4.57 \\
\hline
\end{tabular}

${ }^{1}$ Measured values are the average of ten fruits.

${ }^{2}$ Before hot water treatment. 
TABLE 3-_Properties of Keitt mangos subjected to different immersion intervals in hot water at $46.1^{\circ} \mathrm{C}\left(115^{\circ} \mathrm{F}\right)$.

\begin{tabular}{lrcccc}
\hline & \multicolumn{5}{c}{ Properties after 7 days cold storage $\left(50-55^{\circ} \mathrm{F}, 10-12^{\circ} \mathrm{C}\right)^{2}$} \\
\cline { 2 - 6 } $\begin{array}{l}\text { Interval } \\
\text { (minutes) }\end{array}$ & $\begin{array}{c}\text { Shear } \\
\text { (lbs/g) }\end{array}$ & 'Brix & pH & $\begin{array}{c}\text { Acidity } \\
(\%)\end{array}$ & $\begin{array}{c}\text { Sugars } \\
(\%)\end{array}$ \\
\hline 90 & 0.82 & $\mathbf{1 6 . 8}$ & 3.73 & 0.67 & 14.28 \\
$\mathbf{1 2 0}$ & $\mathbf{0 . 6 7}$ & $\mathbf{1 8 . 2}$ & 3.70 & 0.69 & 15.47 \\
150 & $\mathbf{0 . 6 3}$ & $\mathbf{1 7 . 2}$ & 3.87 & 0.59 & 16.17 \\
180 & $\mathbf{0 . 4 5}$ & $\mathbf{1 8 . 2}$ & 3.85 & 0.60 & 17.11 \\
Control $_{\text {Green state }}^{2}$ & $\mathbf{0 . 5 2}$ & 17.8 & 3.90 & 0.64 & 16.50 \\
\hline
\end{tabular}

Measured values are the average of ten fruits.

"Before hot water treatment.

plete within four and seven days, respectively. Failure to ripen at all was observed in Parvin fruits heated for 180 minutes.

A high percentage of fruit decay was observed for varieties Parvin and Keitt held 24 to 26 days at room temperature following seven days cold storage (table 5). The striking fruit decay was associated with 14 days cold storage, followed by 21 to 26 days at room temperature (Table 5). The Parvin and Keitt varieties had decay in $100 \%$ of their fruits. Of the three varieties tested, Keitt bore the most attractive external appearance by virtue of a lesser degree of decay per fruit.

TABLE 4.-Sensory evaluation, by taste panel, of three mango varieties given variable immersion intervals in hot water $\left(46.1^{\circ} \mathrm{C} ; 115^{\circ} \mathrm{F}\right)$, followed by seven days in cold storage $\left(50-55^{\circ} \mathrm{F} ; 10-12^{\circ} \mathrm{C}\right) ;$ ripe fruit.

\begin{tabular}{|c|c|c|c|c|c|c|}
\hline \multirow[b]{2}{*}{ Variety } & \multirow{2}{*}{$\begin{array}{l}\text { Treatment } \\
\text { (minutes) }\end{array}$} & & \multicolumn{4}{|c|}{ Taste-panel means values, for parameter } \\
\hline & & & Appearance & Flavor & Texture & Aceeptability ${ }^{2}$ \\
\hline Trwin & Control, & $\begin{array}{r}0 \\
90 \\
120 \\
150 \\
180\end{array}$ & $\begin{array}{l}5.50 \\
5.60 \\
5.42 \\
5.72 \\
5.63\end{array}$ & $\begin{array}{l}4.85 \\
4.90 \\
5.50 \\
5.36 \\
4.81\end{array}$ & $\begin{array}{l}5.29 \\
5.10 \\
5.29 \\
5.18 \\
5.09\end{array}$ & $\begin{array}{l}5.00 \\
5.00 \\
5.43 \\
5.36 \\
5.00\end{array}$ \\
\hline Parvin & Control, & $\begin{array}{r}0 \\
90 \\
120 \\
150 \\
180\end{array}$ & $\begin{array}{l}5.33 \\
510 \\
5.32 \\
5.42 \\
5.09\end{array}$ & $\begin{array}{l}5.44 \\
4.26 \\
4.73 \\
5.29 \\
5.38\end{array}$ & $\begin{array}{l}5.22 \\
4.31 \\
4.58 \\
5.29 \\
5.28\end{array}$ & $\begin{array}{l}5.38 \\
4.36 \\
4.95 \\
5.04 \\
5.14\end{array}$ \\
\hline Keitt & Control, & $\begin{array}{r}0 \\
90 \\
120 \\
150 \\
180\end{array}$ & $\begin{array}{l}5.64 \\
5.57 \\
5.57 \\
5.64 \\
5.73\end{array}$ & $\begin{array}{l}4.91 \\
4.88 \\
5.14 \\
5.09 \\
5.09\end{array}$ & $\begin{array}{l}5.27 \\
5.14 \\
5.00 \\
5.00 \\
5.18\end{array}$ & $\begin{array}{l}4.78 \\
4.92 \\
5.28 \\
5.28 \\
5.09\end{array}$ \\
\hline
\end{tabular}

'Taste panels, averaging 16 judges, evaluated samples of 12 fruits, employing a 6-point hedonic seale.

${ }^{2}$ Values greater than 4.0 are considered acceptable. 
TABLE 5.-Decay of mango fruit at room temperature as a function of time after hot water treatment followed by cold storage.

\begin{tabular}{lrcrrrrrr}
\hline & \multicolumn{3}{c}{ Period (days in) - } & \multicolumn{5}{c}{ Deeay (\%), for submersion time (min.) - } \\
\cline { 2 - 8 } Variety & Cold & $\begin{array}{c}\text { Room } \\
\text { Temp. }\end{array}$ & 0 & 90 & 120 & 150 & 180 \\
\hline Irwin & 7 & 19 & 36 & 32 & 50 & 36 & 40 \\
& 14 & 26 & 100 & 59 & 77 & 64 & 86 \\
Parvin & 7 & 26 & 70 & 80 & 70 & 81 & 75 \\
& 14 & 26 & 100 & 100 & 100 & 100 & 100 \\
Keitt & 7 & 24 & 70 & 57 & 75 & 84 & 90 \\
& 14 & 21 & 100 & 100 & 100 & 100 & 100 \\
\hline
\end{tabular}

'The room temperature storage began after fruit removal from cold storage.

In contrast with Irwin variety, in which failure to ripen progressed with increasing time in cold storage, varieties Parvin and Keitt generally ripened more rapidly as the cold-storage interval was lengthened. All varieties displayed a greenish appearance after 14 and 21 days in cold storage, even though they were fully ripe.

The study indicates that mango fruits given the hot-water treatment herein prescribed, and maintained for 7 days in cold storage at $50-55^{\circ} \mathrm{F}$ and $85-90 \% \mathrm{RH}$, should be marketable for about 10 to 12 days at room temperature. If kept 14 days in cold storage after hot-water treatment, they should be marketed within four to five days after removal from the cold.

\section{LITERATURE CITED}

1. Hatton, T. T., Jr. and W. F. Reeder, 1965. Hot water as a commercial control of mango anthraenose. Proc. Carib. Region Soc. Hort. Sci. 9: 5-11.

2. Pennock, W. and G. Maldonado, 1962. Hot water treatment of mango fruits to reduce anthracnose decay. J. Agric. Univ. P. R. 46: 272-83.

3. Ruckleshaus, W. D. 1984. Ethylene dibromide amendment of notice of intent to cancel registration of pestieide products containing ethylene dibromide. Fed. Regist. 49(70): 14182-4185.

4. Segarra, A. 1987. Annual Progress Report. Project Z-39. Agricultural Experiment Stn., Univ. P, R. (1986-87).

5. Sharp, J. L., 1986. Hot water treatment for control of Anastrepha suspensa (Diptera: Tephritidae) in mangos. J. Econ. Entomol. 79: 706-08.

6. __ and D. H. Spalding. 1984. Hot water as a quarantine treatment for Florida mangos infested with Caribbean fruit fly. Proc. Fla. State Hort. Soc. 97: 355-57.

7. Spalding, D. H., 1986. Evaluation of various treatments for control of postharvest decay of Florida mangos. Proc. Fla. State Hort. Soe, 99: 97-99.

8. $\longrightarrow$, and W. F. Reeder, 1986. Decay and acceptability of mangos with combinations of hot water, Imazalil, and gamma-irradiation. Plant Dis. 70: 1149-151. 